\title{
Extraction and Characterization of Native Starch From Black and Red Rice
}

\author{
Henrique Valentim Moura \\ Federal University of Campina Grande (UFCG), Agricultural Engineering Department, \\ 58429-140, Brazil
}

Rennan Pereira de Gusmão, Thaisa Abrantes Souza Gusmão

Federal University of Campina Grande (UFCG), Food Engineering Department, 58429-140, rennangusmao@gmail.com, ta_brantes@hotmail.com, Campina Grande, PB, Brazil

\begin{abstract}
Deise Souza de Castro
Federal University of Campina Grande (UFCG), Agricultural Engineering Department, 58429-140, Brazil
\end{abstract}

\section{Raphael Lucas Jacinto Almeida (Corresponding Author)}

Federal University of Rio Grande do Norte (UFRN), Chemical Engineering Department, 59078-970, raphaelqindustrial@gmail.com, Natal, RN, Brazil

E-mail: raphaelqindustrial@gmail.com

\section{Rossana Maria Feitosa de Figueirêdo}

Federal University of Campina Grande (UFCG), Agricultural Engineering Department, 58429-140, Brazil

Received: Nov. 21, 2019

Accepted: Jan. 3, 2020

Published: Jan. 5, 2020

doi:10.5296/jas.v8i3.16183

URL: https://doi.org/10.5296/jas.v8i3.16183

\begin{abstract}
The objective of the study is to extract and characterize red rice starch, a grain commonly consumed in the Northeast region of Brazil and to compare it with the starch obtained from black rice, widely spread in eastern countries. Starch was extracted by immersion of rice in
\end{abstract}


sodium metabisulfite $(0.2 \%)$, followed by milling, filtration, decantation and drying at $50{ }^{\circ} \mathrm{C}$. The obtained starches were characterized by the following parameters: physicochemical, physical, rheological, textural, structural, thermal and morphological. The highest starch extraction yield was found in red rice grains $(67.84 \%)$, where it obtained higher water absorption and lower apparent viscosity, firmness and gum. Both starch gels indicate the behavior of non-Newtonian fluid in the specific case of pseudoplastic crystallinity type A and with polyhedral geometry. For the thermal analysis of red rice starch, it was observed higher gelatinization temperature and lower gelatinization enthalpy. Black and red rice grains can be considered an alternative source of starch, especially red rice, which has a lower cost due to its production in the country.

Keywords: Oryza sativa, Native starch, Technological properties

\section{Introduction}

The naturally grown pigmented rice cultivars are associated with many health benefits and are found to be present in the diverse shades of colors mainly red, purple, and black. These are highly valued and greater interest has been recently shown in them due to the presence of different polyphenols that are having multiple biological activities (Bhat and Riar, 2019). Rice is a widely consumed food because of its beneficial properties for health, constituting a source of energy due to the high concentration of starch, proteins, minerals and B vitamins (Ziegler et al., 2016). Husked rice has a variety of natural colors, such as brown, red and black, depending on the content of anthocyanins in the episperm. Red rice is rich in nutritional and biofunctional components, such as proanthocyanidins, $\gamma$-aminobutyric acid, $\gamma$-oryzanol, dietary fibers, vitamins and minerals, compared to the common whole rice (Ding et al., 2018). Black rice is a source of phytochemicals, with functional properties and high levels of antioxidants, which serve as protection for endothelial cells, acting in the prevention of cardiovascular diseases (Finocchiaro et al., 2010). Black rice also contains a higher lipid content than non-pigmented and red rice, which makes it more palatable and attractive (Choi et al., 2019).

One of the major constituents of rice is the starch, a polysaccharide with important properties such as biodegradability, biocompatibility and non-toxicity (Afolabi et al., 2012). The interest in rice starch has increased due to its specific characteristics: white color, lack of odor, easy digestion and small particle size. These characteristics allow multiple applications for the starch, in both food and non-food industries (Ashogbon and Akintayo, 2012). Among its functions in the food industry, starch can facilitate processing, impart texture, serve as thickener, provide suspended solids or undergo modifications in its structure to perform specific functions (Silva et al., 2013). The objective of the study is to extract and characterize the red rice starch, a grain commonly consumed in the Northeast region of Brazil and compare it with the starch obtained from black rice that is widespread in the Eastern countries.

\section{Material and Methods}

Black and red rice (Oryza sativa L.) grains, Type 1, Class medium, Subgroup whole, were 
purchased from the local market of the city of Campina Grande - PB, Brazil.

\subsection{Extraction of Native Starches}

Black and red rice starches were extracted according to Adebowale et al. (2005). Rice grains were immersed in sodium metabisulfite $(0.2 \%)$, at $1: 2$ ratio $(\mathrm{m} / \mathrm{v})$ for $48 \mathrm{~h}$, washed in running water for $3 \mathrm{~min}$, crushed in a blender with distilled water at 1:2 rate $(\mathrm{m} / \mathrm{v})$ for $5 \mathrm{~min}$, filtered in organza fabric, and the residue was crushed again three times, to increase process yield. Following filtration, the starch suspension was decanted for $24 \mathrm{~h}$ at $7{ }^{\circ} \mathrm{C}$. After the first decantation, the supernatant was discarded and $300 \mathrm{~mL}$ of distilled water were mixed with the precipitated starch to purify the sample. After more $24 \mathrm{~h}$ of decantation, the supernatant was discarded again and the same volume of water $(300 \mathrm{~mL})$ was mixed with the precipitate. This supernatant disposal and water addition process was performed 5 times. The decanted starch was dried in a forced air circulation oven at $50^{\circ} \mathrm{C}$ until reaching a safe percentage of moisture, which does not allow the development of microorganisms.

\subsubsection{Extraction Yield}

Starch extraction yield was calculated according to Equation 1.

$$
Y=\frac{m s}{m i} \cdot 100
$$

Where, Y- yield, (\%), ms- mass of starch obtained after drying (g), and mi- initial mass of crushed rice $(\mathrm{g})$.

\subsection{Starch Characterization}

\subsubsection{Physicochemical Characterization}

Physicochemical analyses were carried out in triplicate, using the starch retained on the 80-mesh sieve (because it was visually more similar to the existing commercial starches): $\mathrm{pH}$, titratable acidity, moisture content, ashes, starch and lipids were determined according to AACC (2000). Water activity at $25^{\circ} \mathrm{C}$ was determined in an Aqualab 3TE water activity meter (Decagon).

\subsubsection{Water and Oil Absorption Capacity}

The method of Beuchat (1977) was used to determine the water and oil absorption capacity of the starches. Approximately $10 \mathrm{~mL}$ of distilled water or soybean oil were added to $1 \mathrm{~g}$ of starch in centrifuge tubes. The suspension was homogenized for $30 \mathrm{~s}$, left at rest for $30 \mathrm{~min}$ and centrifuged for $15 \mathrm{~min}$ at $1000 \mathrm{rpm}$. The mass of water or oil absorbed (Equation 2) was

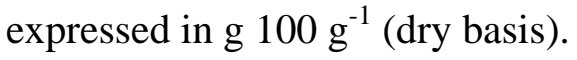

$$
\mathrm{CA}=\text { (tube mass after centrifugation) - (tube mass }+ \text { dry sample). } 100
$$

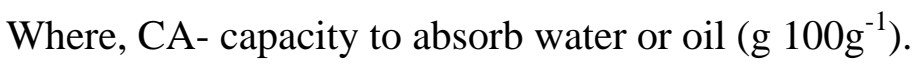




\subsubsection{Syneresis}

The syneresis (Equation 3) of rice starch gels was determined according to Farnsworth et al. (2006). After three days stored at $6{ }^{\circ} \mathrm{C}$, the gels were centrifuged at $3000 \mathrm{rpm}$ for $10 \mathrm{~min}$, where the ratio: starch / water $(1: 10)$ and temperature $\left(80{ }^{\circ} \mathrm{C}\right)$ were standardized in the preparation of suspensions.

$$
\text { Symeresis }(\%)=\frac{m f}{m i} \cdot 100
$$

Where, mf- mass of water separated from the gel after centrifugation $(\mathrm{g})$, and mi- initial mass of the gel $(\mathrm{g})$.

\subsubsection{Rheological Behavior}

The apparent viscosity of the rice starch gels was determined in triplicate using the Brookfield DV-II+Pro viscosimeter at rotation speeds from 50 to $200 \mathrm{rpm}$. Starch-water (10\%) suspensions were heated up to the point of gelatinization $\left(80{ }^{\circ} \mathrm{C} / 30 \mathrm{~min}\right)$, and viscosity readings were taken at gelatinization temperature and room temperature $\left(25^{\circ} \mathrm{C}\right)$. The results were analyzed in Origin 8.0 software.

\subsubsection{Texture}

The texture profile was tested using the TA-XT PLUS texture analyzer (Scarsdale, NY; Stable Micro Systems, UK). Instrument settings were compression mode, trigger type, auto5 g; pretest speed, $2.0 \mathrm{~mm} / \mathrm{s}$; posttest speed, $1.0 \mathrm{~mm} / \mathrm{s}$; test speed, $1.0 \mathrm{~mm} / \mathrm{s}$; compression height, height of samples; strain, $40 \%$; interval between two compressions, $5 \mathrm{~s}$; compression times, 2 $\mathrm{s}$, aluminum cylinder with a diameter of $36 \mathrm{~mm}$ in diameter. Each sample should be measured twice and the final result was the average. The firmness, cohesiveness, guminess and adhesiveness values were calculated from the force-for-time plots obtained (Liu et al., 2015).

\subsubsection{X-ray Diffractograms}

The X-ray diffractograms of the starches were obtained in diffractometer (Shimadzu, XRD 7000 ) using copper $\mathrm{K} \alpha$ radiation $(1.5418 \AA$ ), $40 \mathrm{kV}, 30 \mathrm{~mA}$, step of 0.05 and scanning rate of $0.5^{\circ} \mathrm{min}^{-1}$ at room temperature. The scanning range of the diffraction was adjusted to angles from $5^{\circ}$ to $65^{\circ}(2 \theta)$. The diffractograms were used to identify the phases composing a crystalline material. The diffractogram was read from the graph of the record of counts per second versus diffraction angle $2 \theta$, with the degree of crystallinity obtained according to Equation 4.

$$
\% \text { Crystallinity }=\frac{\text { Total Area-Amorphous Fraction Area }}{\text { Total Area }} .100 \%
$$




\subsubsection{FTIR}

The FT-IR spectra of the starches were obtained using Spectrum 400 from Perkin Elmer in the region of $4000-600 \mathrm{~cm}^{-1}$, using a resolution of $4 \mathrm{~cm}^{-1}$ and $32 \mathrm{scans}$. Gaussian function was used to deconvolute the FTIR peaks.

\subsubsection{Differential Scanning Calorimetry (DSC)}

The thermal properties of black and red rice starch were determined using a differential scanning calorimeter (2920 Modulated DSC, TA Instruments, New Castle, Del., U.S.A.) equipped with a refrigerated cooling system. Starch (12 mg, dry basis) was charged into a high-volume pot and distilled water $(28 \mathrm{mg})$ was added. The samples were sealed and allowed to equilibrate overnight at room temperature before the DSC analysis. The sample pots were heated at a rate of $10{ }^{\circ} \mathrm{C} / \mathrm{min}$ from $20^{\circ} \mathrm{C}$, up to $200{ }^{\circ} \mathrm{C}$. An empty pan was used as a reference. The temperatures onset (To), peak temperature (Tp) and transition enthalpy $(\Delta \mathrm{H})$ were measured from the thermograms.

\subsubsection{Scanning Electron Microscopy}

Starch morphology was analyzed by the technique of Scanning Electron Microscopy (SEM). The samples were prepared by placing the solids on an aluminum sample holder, covered with carbon double-sided tapes, metallized with gold, in order to provide a reflecting surface for the electron beams, and then observed in the VEGA3 Tescan scanning electron microscope under vacuum of $1.5 \times 10^{-3} \mathrm{~Pa}$, with magnification of $2000 \mathrm{x}$.

\subsection{Data Statistical Analysis}

All experiments were executed in triplicate, and the results were submitted to analysis of variance (ANOVA) at 5\% of probability. The significant qualitative responses were submitted to the Tukey test adopting the same level of $5 \%$ of significance. All statistical analyses were developed using Statistica software version 7.0 (Stasoft, 2007).

\section{Results and Discussion}

\subsection{Extraction Yield}

Starch extraction yield was equal to 50.03 and $67.84 \%$ for black rice and red rice, respectively. Ashogbon and Akintayo (2012) studied starches of different rice cultivars and obtained extraction yields from 45.7 to $65 \%$.

\subsection{Physicochemical Analyses and Functional Properties}

The results obtained for physicochemical and physical parameters of black and red rice starches are presented in Table 1. 
Table 1. Physicochemical and physical parameters of black and red rice starches

\begin{tabular}{ccc}
\hline Parameters & Black rice starch & Red rice starch \\
\hline $\mathrm{pH}$ & $5.26 \pm 0.01^{\mathrm{a}}$ & $5.25 \pm 0.01^{\mathrm{a}}$ \\
Acidity $\left(\mathrm{ml} \mathrm{NaOH} 1 \mathrm{~N} 100 \mathrm{~g}^{-1}\right)$ & $3.10 \pm 0.01^{\mathrm{a}}$ & $3.11 \pm 0.03^{\mathrm{a}}$ \\
Moisture content $(\%)$ & $7.83 \pm 0.05^{\mathrm{b}}$ & $12.80 \pm 0.10^{\mathrm{a}}$ \\
Ash $(\%)$ & $0.85 \pm 0.05^{\mathrm{a}}$ & $0.52 \pm 0.02^{\mathrm{b}}$ \\
Starch $(\%)$ & $91.06 \pm 1.12^{\mathrm{a}}$ & $86.54 \pm 0.38^{\mathrm{b}}$ \\
Lipids $(\%)$ & $0.26 \pm 0.02^{\mathrm{a}}$ & $0.14 \pm 0.02^{\mathrm{b}}$ \\
Water activity $\left(\mathrm{A}_{\mathrm{w}}\right)$ & $0.345 \pm 0.006^{\mathrm{a}}$ & $0.328 \pm 0.007^{\mathrm{b}}$ \\
Water absorption $\left(\mathrm{g} 100 \mathrm{~g}^{-1}\right)$ & $99.53 \pm 1.00^{\mathrm{b}}$ & $111.6 \pm 1.82^{\mathrm{a}}$ \\
Oil absorption $\left(\mathrm{g} 100 \mathrm{~g}^{-1}\right)$ & $86.90 \pm 1.37^{\mathrm{a}}$ & $78.90 \pm 0.30^{\mathrm{b}}$ \\
Syneresis $(\%)$ & $13.47 \pm 0.05^{\mathrm{b}}$ & $16.93 \pm 0.11^{\mathrm{a}}$ \\
\hline
\end{tabular}

Note: Means followed by the same lowercase letters in the rows do not differ statistically by Tukey test at 0.05 probability level.

The values of $\mathrm{pH}$ and acidity obtained for red and black rice starches did not differ statistically ( $p>0.05)$. Alencar et al. (2017) obtained for the black rice grain the value of 6.67 for $\mathrm{pH}$, which is higher than the value found in the present study. Ashogbon and Akitayo (2012) observed in the paste of rice starch $\mathrm{pH}$ values from 5.3 to 6.9, which are close the ones found here. According to the current legislation for rice starches (Brazil, 1978), the maximum value allowed is $14 \%$ for moisture content. The starches of the present study are within the standard required by legislation for moisture content. Such higher acidity may be related to the types of rice used, the conditions of cultivation and processing.

Ash and starch contents differed statistically $(\mathrm{p}>0.05)$ between samples, with highest values in black rice starch. Ash contents were lower than 1\%, indicating pure starches. Arns et al. (2015) obtained ash content of $0.20 \%$ in the starch of rice (cv. IRGA-424). Santos et al. (2019) found $1.97 \%$ ash for the black rice grain. An et al. (2016) obtained 69.68\% starch for black rice grain and Almeida et al., 2019 obtained 81.98\% for native red rice starch. The varying content of starch in different rice starch samples could be attributed to variations in environmental conditions during grain development (Asaoka et al., 1985) and cultural practice (Kim and Wiesenborn, 1995). Multiplying the value of the extraction yield by the 
starch content obtained in Table 1, red rice stands out with $56.25 \%$ of pure starch extraction in relation to $41.61 \%$ of black rice.

The lipid contents in the starches differed statistically ( $p>0.05$ ). Low lipid contents were also found by Przetaczek-Roznowska (2017) in starches isolated from pumpkin, which ranged from 0.04 to $0.05 \%$, and by Arns et al. (2015) in rice starches, which varied from 0.03 to $0.07 \%$.

The water activity values obtained for red and black rice starches were not favorable for the development of bacteria (0.90), yeasts (0.80), fungi (0.60), halophile bacteria (0.65) and osmophilic yeasts (0.62), according to Fonseca and Cantarelli (1984).

The water absorption capacity indicates the volume of water absorbed by the starch granules of a certain sample subjected to a thermal treatment. Higher capacity to absorb water was observed in red rice starch. Similar results were reported by Almeida et al. (2013), who studied ying native and modified starch of taro. In relation to the oil absorption capacity, the black rice starch had higher capacity to absorb oil. Falade and Christopher (2015) obtained

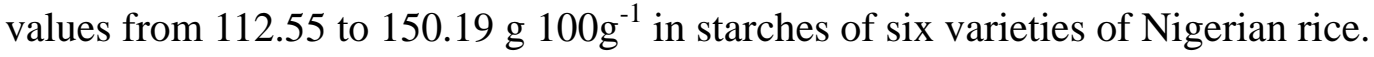

Higher value of syneresis was found in red rice starch, thus revealing that it releases greater volume of water in its handling.

\subsection{Rheological Behavior}

The rheological behavior of the starch gels at temperatures of 25 and $70{ }^{\circ} \mathrm{C}$ can be observed in Figure 1.
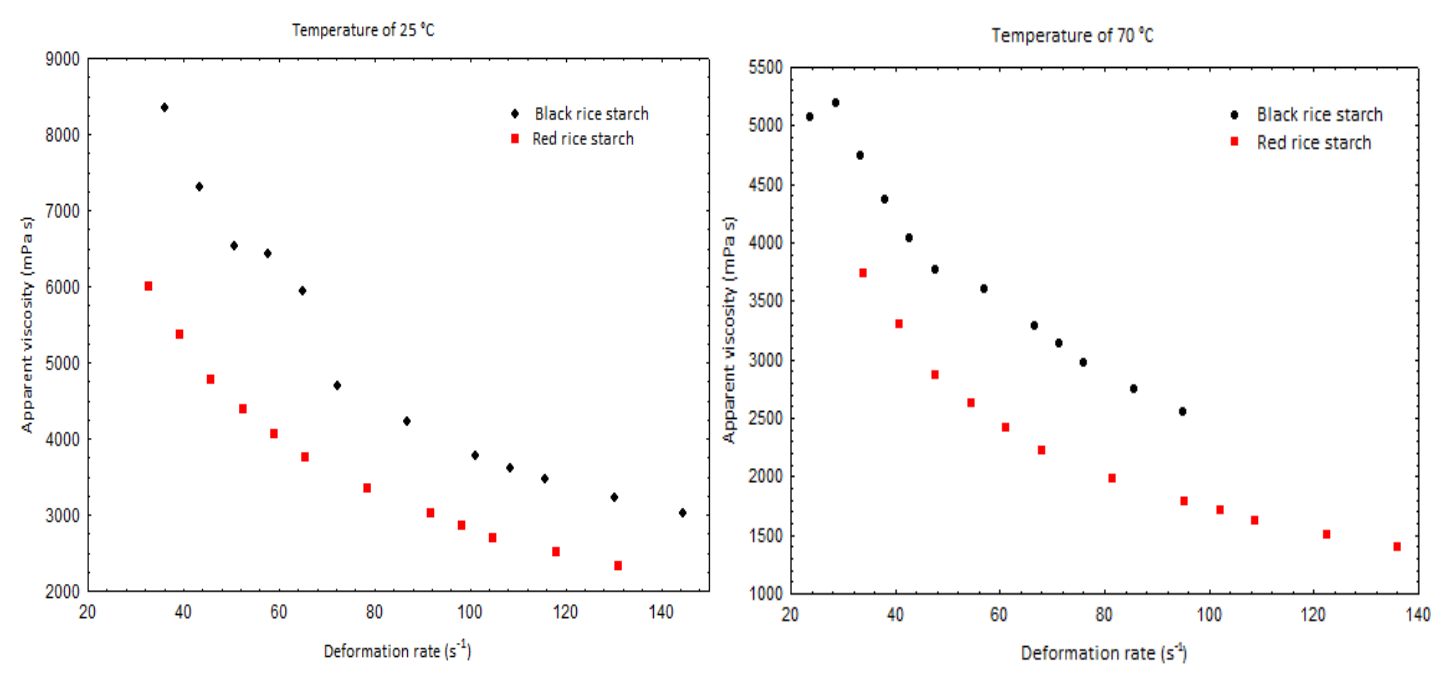

Figure 1. Rheological behavior of gels of black and red rice starches

Apparent viscosity decreased with the increase in deformation rate, indicating a behavior of non-Newtonian fluid with pseudoplastic characteristics. Such pseudoplastic behavior can be explained by the progressive orientation of the soluble starch molecules in the direction of the flow, as well as the disruption of the intramolecular and intermolecular bonding system in the starch network, which increases the sensitivity to the shearing force (Sun and Yoo, 2011). The 


\section{Al Macrothink}

Journal of Agricultural Studies

ISSN 2166-0379

2020, Vol. 8, No. 3

same profile was found by Ma et al. (2019) in their studies with cornstarch added at different pectin concentrations

\subsection{Texture}

Table 2 presents the texture parameters of the starch gels. Firmness corresponds to the force applied to cause deformation in the sample and is correlated with the force to bite and compress the food in the mouth (Kalviainen et al., 2000).

Table 2. Texture parameters of black and red rice starches

\begin{tabular}{ccccc}
\hline Starch source & Firmness (N) & $\begin{array}{c}\text { Cohesiveness } \\
\text { (dimensionless) }\end{array}$ & $\begin{array}{c}\text { Elasticity } \\
(\text { dimensionless })\end{array}$ & $\begin{array}{c}\text { Guminess } \\
(\mathrm{N})\end{array}$ \\
\hline Black rice & $2.98 \pm 0.04^{\mathrm{a}}$ & $0.47 \pm 0.05^{\mathrm{b}}$ & $1.00 \pm 0.02^{\mathrm{a}}$ & $1.41 \pm 0.02^{\mathrm{a}}$ \\
Red rice & $2.16 \pm 0.10^{\mathrm{b}}$ & $0.55 \pm 0.02^{\mathrm{a}}$ & $1.00 \pm 0.08^{\mathrm{a}}$ & $0.96 \pm 0.05^{\mathrm{b}}$ \\
\hline
\end{tabular}

Note: Means followed by the same lowercase letters in the columns do not differ statistically by Tukey test at 0.05 probability level.

The black rice starch showed greater firmness than the red rice starch. Przetaczek-Roznowska (2017) obtained higher firmness values of 11.80 and $22.98 \mathrm{~N}$ for corn and potato, respectively.

It is possible to correlate firmness with the rheological behavior found for the starches, so a greater firmness is directly related to higher viscosity, as observed in Figure 1, which shows that black rice starch showed higher viscosity than red rice starch at the evaluated temperatures.

In the present study, cohesiveness was higher in the red rice starch. Przetaczek-Roznowska (2017) found a lower value (0.2) in corn starch. Elasticity did not differ significantly between the two starches. This property measures the capacity of a product to return to its original form after being subjected to a compression force (Guimarães et al., 2014). Gumminess is the energy required to disintegrate a semi-solid food (Silva et al., 2013), and black rice starch showed higher gumminess than the red rice starch. 


\section{$\triangle$ Macrothink}

\section{$3.5 X$-ray Diffractograms}

The X-ray diffractograms of black and red rice starches Figure 2.

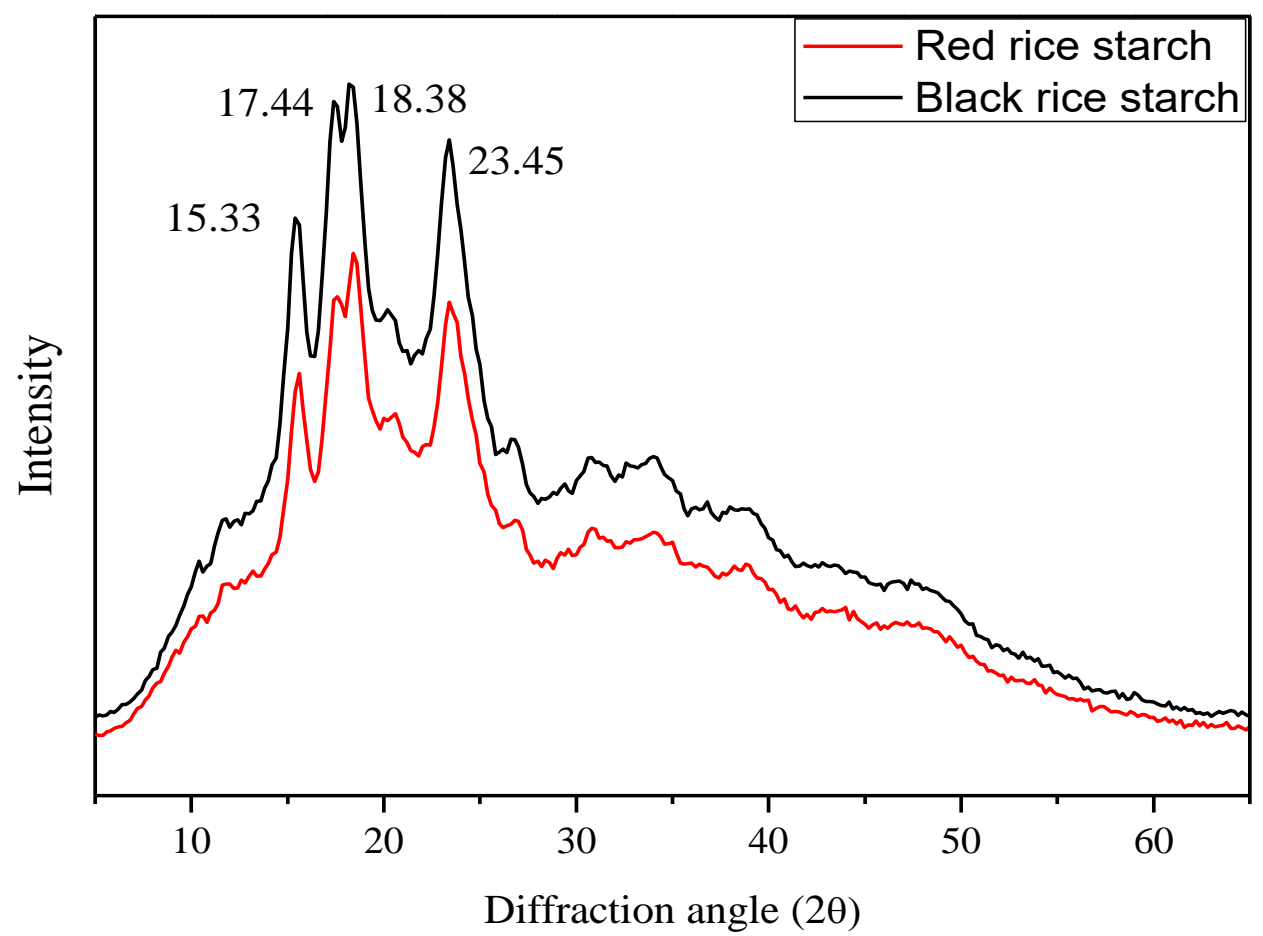

Figure 2. X-ray diffractograms of black and red rice starches

They presented intensity peaks at $2 \theta$ diffraction angles with values of $15.33^{\circ}, 17.44^{\circ}, 18.48^{\circ}$ and $23.45^{\circ}$ for black and red rice starch, being classified as type A crystallinity (Mir et al., 2017). Minor differences in intensity are observed in the diffractogram between black and red rice starch. Ziegler et al. (2017) also found for the crystallinity of the brown, black and red type A rice starch structure, with peaks at $\left(15^{\circ}, 17^{\circ}, 18^{\circ}, 20^{\circ}\right.$ and $\left.23^{\circ}\right)$ according to the classification of Klein et al. (2013). The crystallinity degree obtained for black rice starch was $22.14 \%$ and for red rice starch was $20.88 \%$, which is in agreement with the literature, which says that the degree of crystallinity (Xc) for native regular starches should be between $20 \%$ and $45 \%$ (Van Soest \& Vliegenthart, 1997). According to the studies conducted by Ziegler et al. (2017) who analyzed starch isolated from brown, black and red pericarp whole grains of rice after storage at different temperatures $\left(16,24,32\right.$ and $\left.40{ }^{\circ} \mathrm{C}\right)$, where $\mathrm{X}$-ray patterns showed a type A crystal structure and on the first day of storage, the grains showed $25.2 \%, 26.3 \%$ and $27.6 \%$ relative crystallinity for brown, black and red pericarp grains, respectively. This result is very similar to those shown by Paraginski et al. (2014), with relative crystallinity of $24.9 \%, 23.7 \%$ and $26 \%$ for starch obtained from brown, red and yellow pericarp rice grains, respectively. Acute peaks are associated with the crystalline region, whereas diffuse peaks are associated with the amorphous region of the samples (Dharmaraj et al., 2011). 
3.6 FTIR

The infrared absorption spectra (FTIR) of the black and red rice starches are presented in Figure 3.
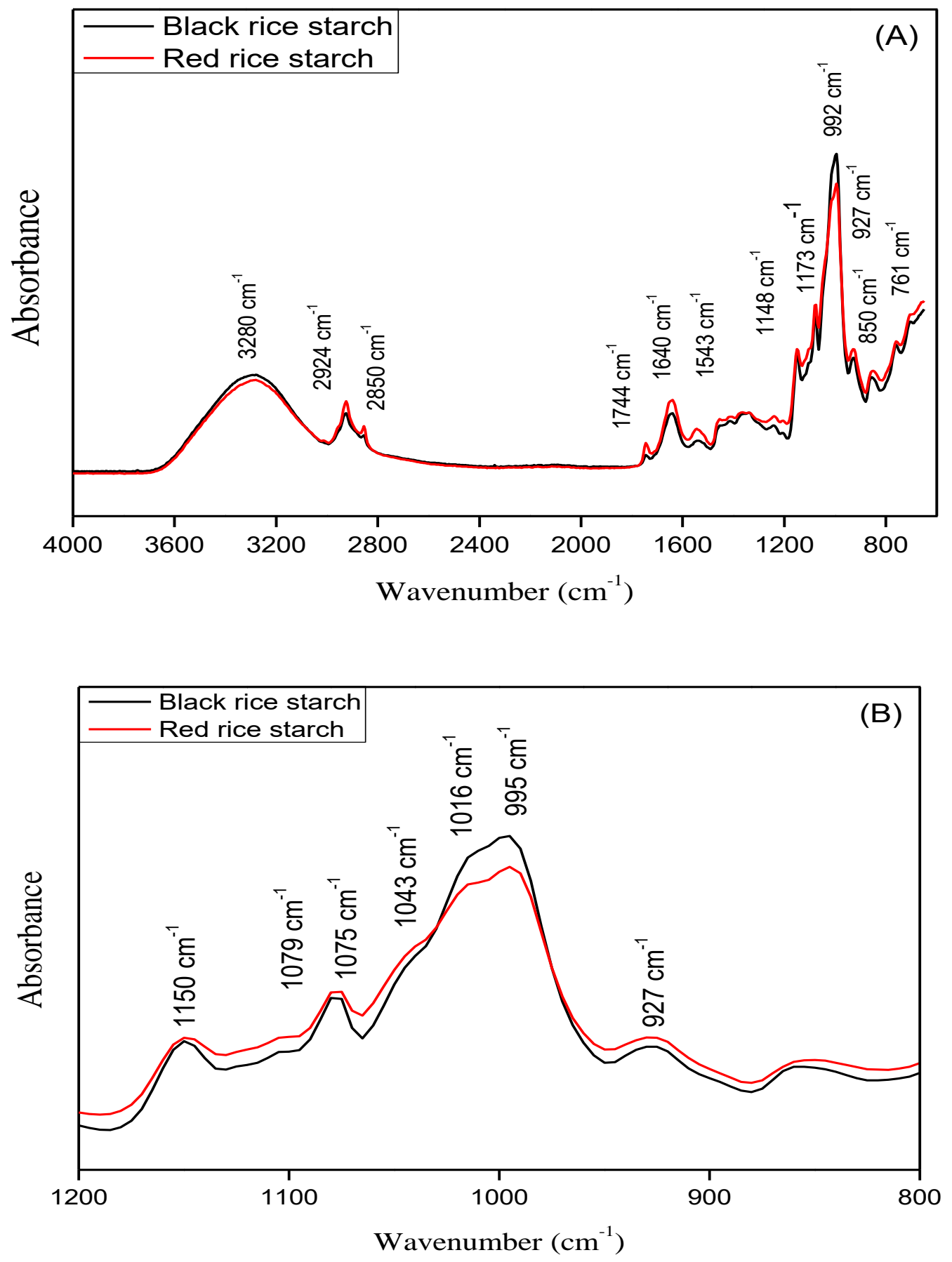

Figure 3. FTIR spectrograms of black and red starch samples (A) full wavelength analyzed (B) close up of $1200-800 \mathrm{~cm}^{-1}$ region

The literature includes evidence of peaks detected in the maximum intensity spectral bands between $854 \mathrm{~cm}^{-1}$ and $1100.50 \mathrm{~cm}^{-1}$, similar to those found in the starches of this study 
(Valencia et al., 2015; Ascheri et al., 2014). The spectrum of native starch has bands in the region of 2900-3000 $\mathrm{cm}^{-1}$ (corresponding to the $\mathrm{C}-\mathrm{H}$ stretch), at 1163, 1150, 1124 and 1103 $\mathrm{cm}^{-1}$, which correspond to the $\mathrm{C}-\mathrm{O}$ and $\mathrm{C}-\mathrm{C}$ stretches with some contribution of the $\mathrm{C}-\mathrm{OH}$ stretch. The bands at 1077, 1067, 1047, 1022, 994 and $928 \mathrm{~cm}^{-1}$ are attributed to the C-OH and $\mathrm{CH}_{2}$ deformations (Zeng et al., 2011).

The bands referring to the molecular deformation existing in the starch molecules at 3400 and $1650 \mathrm{~cm}^{-1}$ are attributed to the stretching and the angular deformation of $-\mathrm{OH}$ bonds, relative to the peak of moisture content. It is possible to observe the band close to $2930 \mathrm{~cm}^{-1}$, attributed to the axial deformation of $\mathrm{C}-\mathrm{H}$ bonds (lipids). The peaks in the region 1600 to $1200 \mathrm{~cm}^{-1}$ are related to $\mathrm{C}-\mathrm{H}$ bending from $\mathrm{CH}_{2}$ and the with hydroxyl bending of alcohols functional groups (Ferraz et al., 2019). Bands in 1000 to $1200 \mathrm{~cm}^{-1}$ region are considered characteristic starch bands and are attributed to the $\mathrm{C}-\mathrm{OH}$ stretching and bending, the $\mathrm{C}-\mathrm{O}-\mathrm{C}$ from the glycoside link, and the CO and CC stretching (Pozo et al., 2018). The vibrations of amylose and amylopectin, which are the main components of starch, were observed in the regions below $1000 \mathrm{~cm}^{-1}$ (Zeng et al., 2011). Minor differences in intensity are observed between black and red rice starch.

\subsection{Differential Scanning Calorimetry}

The results of DSC analysis are presented in Table 3, for the parameters: enthalpy variation $(\Delta \mathrm{H})$ and temperatures of the thermal events.

Table 3. Values obtained in the DSC analysis for black and red rice starches.

\begin{tabular}{ccc}
\hline Parameters & Black rice starch & Red rice starch \\
\hline $\mathrm{T}_{0}\left({ }^{\circ} \mathrm{C}\right)$ (gelatinization temperature) & 57.45 & 70.46 \\
$\mathrm{~T}_{\mathrm{p}}\left({ }^{\circ} \mathrm{C}\right)$ & 63.42 & 75.45 \\
$\mathrm{~T}_{\mathrm{p}}-\mathrm{T}_{0}\left({ }^{\circ} \mathrm{C}\right)$ & 5.97 & 4.99 \\
$\Delta \mathrm{H}\left(\mathrm{J} \mathrm{g}^{-1}\right)$ (gelatinization enthalpy) & 3.51 & 2.85 \\
\hline
\end{tabular}

It can be observed that the gelatinization temperature $\left(T_{0}\right)$ and peak temperature $\left(T_{p}\right)$ of red rice starch was higher than that of black rice starch, demonstrating that the latter requires less energy for the swelling of particles through water absorption and increase of temperature (gelatinization). These values are similar to those found by Almeida et al. (2019) for native red rice starch. Bhat and Riar, (2019) found Tp values ranging from 62.53 to $67.84{ }^{\circ} \mathrm{C}$ for starches obtained from different varieties of pigmented rice. Weber et al., (2009) observed for corn starch gelatinization temperatures between 64 and $105{ }^{\circ} \mathrm{C}$. Arns et al. (2015) found for rice starch higher values of gelatinization enthalpy, varying from 6.47 to $9.13 \mathrm{~J} \mathrm{~g}^{-1}$. Fabian et al. (2011) found for rice bran starch a gelatinization temperature of $72.6^{\circ} \mathrm{C}$ and a gelatinization enthalpy around $9.5 \mathrm{~J} \mathrm{~g}-1$; It is noteworthy that $\Delta \mathrm{H}$ of black and red rice 


\section{Macrothink}

Journal of Agricultural Studies

ISSN 2166-0379

2020, Vol. 8, No. 3

starches are smaller, so it can be stated that the granules are poorly resistant to breakage with prolonged heating. It can be observed that the gelatinization temperature was higher in black rice starch, which indicates a greater loss of molecular organization or breakdown of hydrogen bonds in the granule (Alvani et al., 2011).

\subsection{Scanning Electron Microscopy}

The micrographs of the starches are presented in Figure 4, which shows high similarity between black and red rice starches, both with disordered polyhedral structure, smooth surface and no cracks.
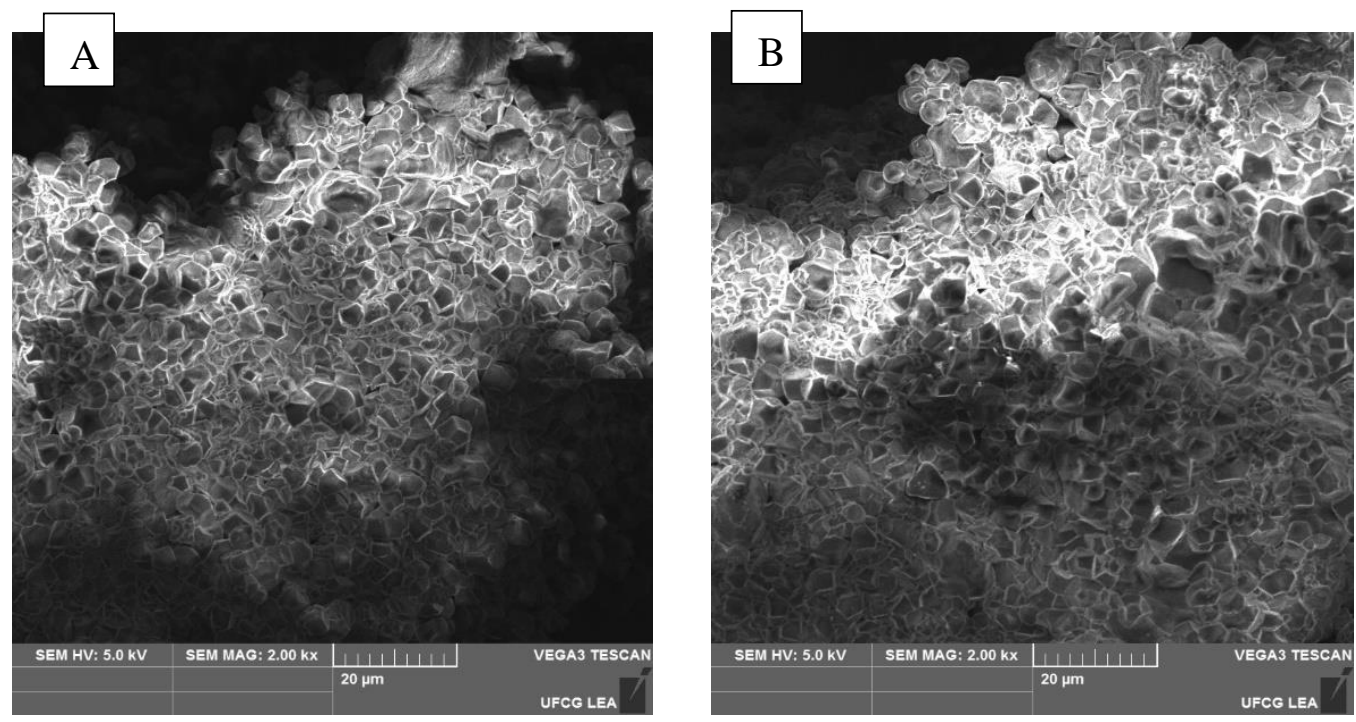

Figure 4. Micrographs of black rice starch (A) and red rice starch (B) magnified 2000 times.

The average sizes of starch granules were $3.38 \mu \mathrm{m}$ for black rice and $3.55 \mu \mathrm{m}$ for red rice, which are similar to the average size of rice starch granules ( 3 to $8 \mu \mathrm{m}$ ) reported by Souza $e t$ al. (2016).

Smooth starch surfaces with no cracks suggest purity in its extraction, but the morphological characteristics may vary according to the plant cultivar, growth stage, environmental conditions and methods of extraction and purification (Oyeyinka and Oyeyinka, 2018).

The red rice starch granules presented an irregular shape with edges and a polyhedral or polygonal geometry, where all surfaces are multi-faceted as reported by (Ramos et al., 2019; Almeida et al., 2019). Ziegler et al. (2017) found the same geometry for the starch granules obtained from brown, black and red rice and did not observe significant differences due to the grain pericarp coloration. Small differences in the appearance of the surfaces of the starch granules may be due to and the milling process of the rice during starch extraction. 


\section{Conclusion}

Red rice presented higher extraction yield, while black rice showed higher purity. Both starch gels showed non-Newtonian pseudoplastic fluid behavior. The gelatinization temperature was higher in red rice starch, but the highest gelatinization enthalpy was found in black rice starch, which may indicate that black rice starch requires greater resistance to breakdown of its crystal structure. Both starches are classified as type a crystallinity and with polyhedral geometry. According to the quality presented by starches, they are suitable for use in various areas of food and non food industry, and black and red rice grains can be considered an alternative source for starch, especially the red rice that has lower cost due to its production in the country.

\section{References}

Adebowale, K. O., Olu-Owolabi, B. I., KehindeOlawumi, E., \& Lawal, O. S. (2005). Functional properties of native, physically and chemically modified breadfruit (Artocarpusartilis) starch. Industrial Crops and Products, 21, 343-351. https://doi.org/10.1016/j.indcrop.2004.05.002

Afolabi, T. A., Olu-Owolabi, B. I., Adebowale, K. O., Awal, O. S., \& Akintayo, C. O. (2012). Functional and tableting properties of etylated and oxidised finger millet (Eleusinecoracana) starch. Starch-Stärke, 64, 326-337. https://doi.org/10.1002/star.201100151

Alencar, D. D. O., Moura, H. V., Gusmão, R. P., \& Gusmão, T. A. S. (2017). Physical-chemical and granulometric characterization of black rice flour. Revista Higiene Alimentar, 31, 1415-1417.

Almeida, E. C., Bora, P. S., \& Zárate, N. A. H. (2013). Amido nativo e modificado de taro (colocasiaesculenta 1. schott): caracterização química, morfológica e propriedades de pasta. B.CEPPA, 31, 67-82. https://doi.org/10.5380/cep.v31i1.32703

Almeida, R. L. J., Pereira T. S., Freire, V. A., Santiago, A. M., Oliveira, H. M. L., Conrado, L. S., \& Gusmão, R. P. (2019). Influence of enzymatic hydrolysis on the properties of red rice starch. International Journal of Biological Macromolecules.

https://doi.org/10.1016/j.ijbiomac.2019.09.072

Alvani, K., Qi, X., Tester, R., \& Snape, C. E. (2011). Physico-chemical properties of potato starches. Food Chemistry, 125, 958-965. https://doi.org/10.1016/j.foodchem.2010.09.088

American Association of Cereal Chemists-AACC (2000). Approved Methods of the American Association of Cereal Chemists.10.ed. Saint Paul: AACC. CD-ROM.

An, J. S., Bae, I. Y., Han, S. I., Lee, S. J., \& Lee, H. G. (2016). In vitro potential of phenolic phytochemicals from black rice on starch digestibility and rheological behaviors. Journal of cereal science, 70, 214-220. https://doi.org/10.1016/j.jcs.2016.06.010

Arns, B., Bartz, J., Radunz, M., Evangelho, J. A. D., Pinto, V. Z., Zavareze, E. D. R., \& Dias, A. R. G. (2015). Impact of heat-moisture treatment on rice starch, applied directly in grain paddy rice or in isolated starch. LWT-Food Science and Technology, 60. 
https://doi.org/10.1016/j.lwt.2014.10.059

Asaoka, M., Okuno, K., \& Fuwa, H. (1985). Effect of environmental temperature at the milky state on amylose content and fine structure of amylopectin of waxy and nonwaxy endosperm starches of rice (Oryza sativa L.). Agricultural Biological Chemistry, 49, 373-379. https://doi.org/10.1271/bbb1961.49.373

Ascheri, D. P. R., Morais, C. C., Asquieri, E. R., Carvalho, C. W. P., \& Ascheri, J. L. R. (2014). Characterization of starch extracted from the roots of Cissus simsiana Roem. \& $\begin{array}{llll}\text { Schult. } \quad \text { Semina: } & \text { Ciências } & \text { 78rárias, } & \text { 35(2), }\end{array}$ https://doi.org/10.5433/1679-0359.2014v35n2p787

Ashogbon, A. O., \& Akintayo, E. T. (2012). Morphological, functional and pasting properties of starches separated from rice cultivars grown in Nigeria. International Food Research Journal, 19, 665-671.

Beuchat, L. R. (1977). Functional and electrophoretic characteristics of succinylated peanut flour protein. Journal of Agricultural and Food Chemistry, 25, 258-261.

https://doi.org/10.1021/jf60210a044

Bhat, F. M., \& Riar, C. S. (2019). Effect of chemical composition, granule structure and crystalline form of pigmented rice starches on their functional characteristics. Food Chemistry, 297, 124984. https://doi.org/10.1016/j.foodchem.2019.124984

Brazil. Resolution No. 12/78 of the National Commission of Food Standards and Standards. Approves the special technical standards of the State of São Paulo, reviewed by CNNPA regarding food (and beverages). Official Gazette of the Federative Republic of Brazil, Brasilia, July 1978. Section 1, pt.I.

Choi, S., Seo, H. S., Lee, K. R., Lee, S., \& Lee, J. (2019). Effect of milling and long-term storage on volatiles of black rice (Oryza sativa L.) determined by headspace solid-phase microextraction with gas chromatography-mass spectrometry. Food Chemistry, 276, 572-582. https://doi.org/10.1016/j.foodchem.2018.10.052

Dharmaraj, U., Parameswara, P., Somashekar, R., \& Malleshi, N. G. (2011). Effect of processing on the microstructure of finger millet 5 by x-ray diffraction and scanning electron microscopy. Journal of Food Science and Technology, 51, 494-502.

https://doi.org/10.1007/s13197-011-0536-4

Ding, J., Ulanov, A. V., Dong, M., Yang, T., Nemzer, B. V., Xiong, S., ... Feng, H. (2018). Enhancement of gama-aminobutyric acid (GABA) and other health-related metabolites in germinated red rice (Oryza sativa L.) by ultrasonication. Ultrasonics Sonochemistry, 40, 791-797. https://doi.org/10.1016/j.ultsonch.2017.08.029

Fabian, C., Ayucitra, A., Ismadji, S., \& Ju, Y. H. (2011). Isolation and characterization of starch from defatted rice bran. Journal of the Taiwan Institute of Chemical Engineers, 42(1), 86-91. https://doi.org/10.1016/j.jtice.2010.03.013

Falade, K. O., \& Christopher, A. S. (2015). Physical, functional, pasting and thermal 
properties of flours and starches of six Nigerian rice cultivars. Food Hydrocolloids, 44, 478-490. https://doi.org/10.1016/j.foodhyd.2014.10.005

Farnsworth, J. P., Li, J., Hendricks, G. M., \& Guo, M. R. (2006). Effects of transglutaminase treatment on functional properties and probiotic culture survivability of goat milk yogurt. Small Ruminant Research, 65, 113-121. https://doi.org/10.1016/j.smallrumres.2005.05.036

Ferraz, C. A., Fontes, R. L., Fontes-Sant'Ana, G. C., Calado, V., López, E. O., \& Rocha-Leão, M. H. (2019). Extraction, Modification, and Chemical, Thermal and Morphological Characterization of Starch From the Agro-Industrial Residue of Mango (Mangifera indica L) var. Ubá. Starch-Stärke, 71(1-2), 1800023. https://doi.org/10.1002/star.201800023

Finocchiaro, F, Ferrari, B., \& Gianinetti, A. (2010). A study of biodiversity of flavonoid content in the rice caryopsis evidencing simultaneous accumulation of anthocyanins and proanthocyanidins in a black-grained genotype. Journal of Cereal Science, 51, 28-34. https://doi.org/10.1016/j.jcs.2009.09.003

Fonseca, H., \& Cantarelli, P. R. (1984). Princípios e métodos gerais de conservação de alimentos pelo controle da umidade, por preservativos e por radiações: embalagens. In: Camargo, R., Fonseca, H. Tecnologia dos produtos agropecuários: alimentos, 97-112.

Guimarães, F. I. T., Caliari, M., \& Soares Junior, M. S. (2014). Instrumental analysis of texture, color and acceptance of instante dessert formulated with broken-rice grains. Food Sciene and Technology Research, 20, 1-8. https://doi.org/10.3136/fstr.20.785

Kalviainen, N., Roininen, K., \& Tuorila, H. (2000). Sensory characterization of texture and flavor of high viscosity gels made with different thickeners. Journal of Texture Studies, 31, 407-420. https://doi.org/10.1111/j.1745-4603.2000.tb00299.x

Kim, Y. S., \& Wiesenborn, D. P. (1995). Starch noodle quality as related to genotypes. Journal of Food Science, 61, 248-252. https://doi.org/10.1111/j.1365-2621.1996.tb14771.x

Klein, B., Pinto, V. Z., Vanier, N. L., Zavareze, E. R., Colussi, R., Evangelho, J. A., Gutkoski, L. C., \& Dias, A. R. G. (2013). Effect of single and dual heat-moisture treatments on properties of rice, cassava, and pinhao starches. Carbohydrate Polymers, 98, 1578-1584. https://doi.org/10.1016/j.carbpol.2013.07.036

Liu, C., Liu, L., Li, L., Hao, C., Zheng, X., Bian, K., ... \& Wang, X. (2015). Effects of different milling processes on whole wheat flour quality and performance in steamed bread making. LWT-food Science and Technology, 62(1), 310-318.

https://doi.org/10.1016/j.lwt.2014.08.030

Ma, Y. S., Pan, Y., Xie, Q. T., Li, X. M., Zhang, B., \& Chen, H. Q. (2019). Evaluation studies on effects of pectin with different concentrations on the pasting, rheological and digestibility properties of corn starch. Food chemistry, 274, 319-323.

https://doi.org/10.1016/j.foodchem.2018.09.005

Mir, S. A., Bosco, S. J. D., Bashir, M., Shah, M. A., \& Mir, M. M. (2017). Physicochemical and structural properties of starches isolated from corn cultivars grown in Indian temperate 
climate. International Journal of Food Properties, 20, 821-832.

https://doi.org/10.1080/10942912.2016.1184274

Oyeyinka, S. A., \& Oyeyinka, A. T. (2018). A review on isolation, composition, physicochemical properties and modification of Bambara groundnut starch. Food Hydrocolloids, 75, 62-71. https://doi.org/10.1016/j.foodhyd.2017.09.012

Paraginski, R. T., do Evangelho, J. A., Colussi, R., Marques e Silva, R., da Rosa Zavareze, E., de Oliveira, M., ... \& Guerra Dias, A. R. (2014). Starch and flour from defective rice kernels and their physicochemical properties. Starch-Stärke, 66(7-8), 729-737. https://doi.org/10.1002/star.201300291

Pozo, C., Rodríguez-Llamazares, S., Bouza, R., Barral, L., Castaño, J., Müller, N., \& Restrepo, I. (2018). Study of the structural order of native starch granules using combined FTIR and XRD analysis. Journal of Polymer Research, 25(12), 266. https://doi.org/10.1007/s10965-018-1651-y

Przetaczek-Roznowska, I. (2017). Physicochemical properties of starches isolated from pumpkin compared with potato and corn starches. International Journal of Biological Macromolecules, 101, 536-542. https://doi.org/10.1016/j.ijbiomac.2017.03.092

Ramos, A. H., Rockenbach, B. A., Ferreira, C. D., Gutkoski, L. C., \& de Oliveira, M. (2019). Characteristics of Flour and Starch Isolated from Red Rice Subjected to Different Drying Conditions. Starch-Stärke. https://doi.org/10.1002/star.201800257

Santos, N. C., Silva, W. P., Barros, S. L., Araújo, A. D. B., Gomes, J. P., Almeida, R. L. J., ... \& Figueirêdo, R. M. F. (2019). Study on Drying of Black Rice (Oryza sativa L.) Grains: Physical-Chemical and Bioactive Quality. Journal of Agricultural Science, 11(9), 203. https://doi.org/10.5539/jas.v11n9p203

Silva, G. A. S., Cavalcanti, M. T., Almeida, M. C. B. M., Araújo, A. S., Chinelate, G. C. B., \& Florentino, E. R. (2013). Utilização do amido da amêndoa da manga Tommy Atkins como espessante em bebida láctea. Revista Brasileira de Engenharia Agrícola e Ambiental, 17, 1326-1332. https://doi.org/10.1590/S1415-43662013001200011

Souza, D., Sbardelotto, A. F., Ziegler, D. R., Marczak, L. D. F., \& Tessaro, I. C. (2016). Characterization of rice starch and protein obtained by a fast alkaline extraction method, Food Chemistry, 191, 36-44. https://doi.org/10.1016/j.foodchem.2015.03.032

Stasoft. STATISTICA 7.0 for Windows - Computar program manual. Tulsa: Statsoft, Inc., 2007. CD Room.

Sun, D., \& Yoo, B. (2011). Rheological and thermal properties of blend systems of rice flour and potato starch. Food Science and Biotechnology, 20, 1679-1684. https://doi.org/10.1007/s10068-011-0231-2

Valencia, G. A., Moraes, I. C. F., Lourenço, R. V., Bittante, A. M. Q. B., \& Sobral, P. J. D. A. (2015). Physicochemical, morphological, and functional properties of flour and starch from peach palm (Bactris gasipaes K.) fruit. Starch-Stärke, 67(1-2), 163-173. 
https://doi.org/10.1002/star.201400097

Van Soest, J. J., \& Vliegenthart, J. F. (1997). Crystallinity in starch plastics: consequences for material properties. Trends in biotechnology, 15(6), 208-213.

https://doi.org/10.1016/S0167-7799(97)01021-4

Weber, F. H., Clerici, M. T. P., Collares-Queiroz, F. P., \& Chang, Y. K. (2009). Interaction of guar and xanthan gums with starch in the gels obtained from normal, waxy and high-amylose corn starches. Starch-Stärke, 61(1), 28-34. https://doi.org/10.1002/star.200700655

Zeng, J., Li, G., Gao, H., \& Ru, Z. (2011). Comparison of A and B starch granules from three wheat varieties. Molecules, 16, 10570-10591. https://doi.org/10.3390/molecules161210570

Ziegler, V., Ferreira, C. D., Goebel, J. T. S., El Halal, S. L. M., Santetti, G. S., Gutkoski, L. C., da Rosa Zavareze, E., \& Elias, M. C. (2017). Changes in properties of starch isolated from whole rice grains with brown, black, and red pericarp after storage at different temperatures. Food Chemistry, 216, 194-200. https://doi.org/10.1016/j.foodchem.2016.08.045

\section{Copyright Disclaimer}

Copyright for this article is retained by the author(s), with first publication rights granted to the journal.

This is an open-access article distributed under the terms and conditions of the Creative Commons Attribution license (http://creativecommons.org/licenses/by/4.0/). 